\title{
Association of VIPR-1 gene polymorphisms and haplotypes with egg production in laying quails*
}

\author{
Yue-jin $\mathrm{PU}^{\dagger 1,2}$, Yan $\mathrm{WU}^{2}$, Xiao-juan $\mathrm{XU}^{2}$, Jin-ping DU², Yan-zhang GONG ${ }^{\dagger 1}$ \\ ( ${ }^{1}$ Key Laboratory of Agricultural Animal Genetics, Breeding, and Reproduction of the Ministry of Education, \\ Huazhong Agricultural University, Wuhan 430070, China)
}

$\left({ }^{2}\right.$ Hubei Key Laboratory of Animal Embryo Engineering and Molecular Breeding, Hubei Academy of Agriculture Sciences, Wuhan 430064, China) †E-mail: puyuejin@yeah.net; poultry@mail.hzau.edu.cn

Received Aug. 22, 2015; Revision accepted Dec. 20, 2015; Crosschecked July 13, 2016

\begin{abstract}
The laying quail is a worldwide breed which exhibits high economic value. In our current study, the vasoactive intestinal peptide receptor-1 (VIPR-1) was selected as the candidate gene for identifying traits of egg production. A single nucleotide polymorphism (SNP) detection was performed in 443 individual quails, including 196 quails from the $\mathrm{H}$ line, 202 quails from the $\mathrm{L}$ line, and 45 wild quails. The SNPs were genotyped using a polymerase chain reaction-restriction fragment length polymorphism (PCR-RFLP). Two mutations (G373T, A313G) were detected in all the tested quail populations. The associated analysis showed that the SNP genotypes of the VIPR-1 gene were significantly linked with the egg weight of G373T and A313G in 398 quails. The quails with the genotype GG always exhibited the largest egg weight for the two mutations in the $H$ and $L$ lines. Linkage disequilibrium (LD) analysis indicated that G373T and A313G loci showed the weakest LD. Seven main diplotypes from the four main reconstructed haplotypes were observed, indicating a significant association of diplotypes with egg weight. Quails with the h1h2 (GGGT) diplotype always exhibited the smallest egg weight and largest egg number at 20 weeks of age. The overall results suggest that the alterations in quails may be linked with potential major loci or genes affecting reproductive traits.
\end{abstract}

Key words: Laying quail, Haplotypes, VIPR-1 gene, Egg production traits http://dx.doi.org/10.1631/jzus.B1500199

CLC number: Q75

\section{Introduction}

In the poultry industry, the aim of modern breeding is to create high-performance poultry lines (Kulibaba and Podstreshnyi, 2012), which has always been of primary interest to breeders and farmers. Many experiments have confirmed that both production and reproductive traits depend on genetic factors (King'ori, 2011; Miazi et al., 2012). In birds, egglaying is the consequence of a complex cascade of

\footnotetext{
Corresponding author

* Project supported by the Open Project of Hubei Key Laboratory of Animal Embryo and Molecular Breeding (No. 2015ZD146), China (1) ORCID: Yue-jin PU, http://orcid.org/0000-0003-3173-427X

(C) Zhejiang University and Springer-Verlag Berlin Heidelberg 2016
}

progressive maturational events involving the entire hypothalamic-pituitary-gonadal axis. Many steroid hormones and their receptors involved in this process play pivotal roles throughout vertebrate reproduction and development $(\mathrm{Li}, 2014)$. Vasoactive intestinal peptide (VIP), a prolactin (PRL) releasing factor, can promote PRL secretion. As a receptor of VIP, VIPR is activated by VIP to give rise to secretion and release of PRL (el Halawani et al., 1990). The VIPR gene has proved to be involved in the regulation of broodiness in avian, as evidenced by the endocrine mechanism of broodiness and expression in vivo and in vitro (Rozenboim and el Halawani, 1993; Kansaku et al., 2001; Chaiseha et al., 2004). The VIPR-1 gene was expressed in the hypothalamus and pituitary, primarily 
in the latter, and only the differential mRNA expression of the VIPR- 1 gene in the pituitary was associated with reproductive changes (You et al., 2001), suggesting that the VIPR- 1 gene is an important candidate gene for egg-laying quails.

The quail egg, an important by-product of laying quails, is believed to be a good tonic and contain high nutrition, also known as "ginseng in animals." In the present study, VIPR-1 was chosen as the candidate gene to analyze its genetic effects on three quail populations. Based on the two-tailed test method, two single nucleotide polymorphisms (SNPs) of the candidate QTL region were selected to analyze their association with egg production traits.

\section{Materials and methods}

\subsection{Sample collection and preparation}

A total of 443 female quails from northeast China were collected for this study, including 196 quails from the $\mathrm{H}$ line, 202 quails from the $\mathrm{L}$ line, and 45 wild quails. The $\mathrm{H}$ and $\mathrm{L}$ line populations were raised in the same farm for 10 years and selected due to their differences in feather color and laying performance, with a higher egg number for the $\mathrm{H}$ line and a higher egg weight for the $\mathrm{L}$ line. The wild quails were caught and raised in the same farm. The egg production traits of 398 quails were recorded throughout the egg production process in terms of body weight for the first egg, age at first laying, egg weight after 12 weeks, and body weight and egg number after 20 weeks of age, but no traits were recorded for the 45 wild quails, because of their low degree of domestication. The blood samples of all the 443 individual quails were collected for further SNP analysis. Genome DNA was extracted from the blood using a blood DNA extraction kit (Lifefeng, China). The DNA samples were dissolved in a Tris-ethylene diamine tetraacetic acid (EDTA) (TE) buffer and stored at $-20^{\circ} \mathrm{C}$. All birds were raised in floor pens and had free access to feed and water. Commercial corn-soybean diets, that meet all National Research Council requirements, were used in this research.

\subsection{Primer design and PCR amplification}

Based on the VIPR- 1 gene sequences of the quail (Zhou et al., 2012), chicken, and turkey (Gene ID: 395329 and 7433), four pairs of primers (Table 1; named as P1, P2, P3, P4) were designed to amplify the target regions for the SNP genotyping using the Primer 5.0 program (Clarke and Gorley, 2001). The detailed information for these primers is listed in Table 1.

Polymerase chain reaction (PCR) was carried out in a total volume of $15 \mu \mathrm{l}$ consisting of $40 \mathrm{ng}$ genomic DNA, 0.5 pmol each primer, $1.5 \mu 110 \times$ buffer, $1.5 \mathrm{mmol} / \mathrm{L} \mathrm{MgCl}_{2}, 0.25 \mathrm{mmol} / \mathrm{L}$ dNTP mixture, and $1.5 \mathrm{U}$ Taq DNA polymerase (Fermentas, Canada). The conditions of PCR were as follows: $95{ }^{\circ} \mathrm{C}$ for $5 \mathrm{~min}$, followed by 35 cycles of $94{ }^{\circ} \mathrm{C}$ for $35 \mathrm{~s}$, annealing temperature $\left(T_{\mathrm{m}}\right)$ for $35 \mathrm{~s}, 72{ }^{\circ} \mathrm{C}$ for $1 \mathrm{~min}$, and a final extension of $72{ }^{\circ} \mathrm{C}$ for $10 \mathrm{~min}$.

\subsection{Polymorphism screening and sequencing}

Genomic DNA from quails was used as the template to amplify the target fragments using the four pairs of primers, and the purified PCR products were sequenced commercially (AuGCT, China). The sequences were aligned to find the base variations using ClustalW (http://www.ebi.ac.uk/Tools/msalclustalw2). A total of 443 samples were subjected to genotyping using the PCR-restriction fragment length polymorphism (PCR-RFLP). For the PCR-RFLP profile,

Table 1 Primers used for analysis of the VIPR-1 gene in quail

\begin{tabular}{ccccc}
\hline Primer & Product size $(\mathrm{bp})$ & \multicolumn{1}{c}{ Primer sequence $\left(5^{\prime} \rightarrow 3^{\prime}\right)$} & Amplified region & Annealing temperature $\left({ }^{\circ} \mathrm{C}\right)$ \\
\hline P1 & 958 & F: GCGTTCTATGGCACAGTTA & Exons 4-5 & 54.0 \\
& & R: AAAGCAATGTTCGGGTCT & & 58.7 \\
P2 & 1492 & F: GCTGCTGGTGGAAGGGTTA & Exons 6-7 & \\
& & R: CCGTCCAAGCAGTGATGAA & & 53.4 \\
P3 & 2101 & F: GTGTTCATCACTGCTTGGA & Exons 7-8 & \\
& \multirow{2}{*}{1660} & R: AATGGAGACCAAAATAGGA & & 54.0 \\
P4 & F: GTGGTGGCTGTCCTCTACT & Exons 11-12 & \\
& & R: CACTGCCCTGCTCATTAA & & \\
\hline
\end{tabular}


$8.0 \mu \mathrm{l}$ of PCR products were digested with $5 \mathrm{U}$ restriction endonuclease (NEB, America) for $6 \mathrm{~h}$ at $37^{\circ} \mathrm{C}$ or for 30 min at $65^{\circ} \mathrm{C}$, followed by separation through using electrophoresis on a $1.0 \%(0.01 \mathrm{~g} / \mathrm{ml})$ agarose gel with ethidium bromide in a $1 \times$ Trisacetate-EDTA (TAE) buffer.

\subsection{Statistical analysis and haplotype construction}

Pairwise tests for linkage disequilibrium (LD) were performed for each SNP using the SHEsis online software platform (http://analysis.bio-x.cn/myAnalysis.php). Haplotypes were constructed based on using two SNPs for all of the 443 quails using the PHASE 2.1 program. The genotypic frequencies were calculated for each individual and the Hardy-Weinberg equilibrium was analyzed using the Chi-square test of PopGene Version 1.3.1. The egg production traits were compared among the genotypes. The association between the SNPs and different traits in 398 quails were analyzed using SPSS 13.0 with the model $Y=\mu+G+L+G \times L+e$, where $Y$ is the dependent variable (analyzed traits), $\mu$ is the overall mean, $G$ is the genotype with a variation for the candidate gene, $L$ is the quail population, $G \times L$ is the interaction between the genotype and quail population (a fixed effect), and $e$ is the random error. The differences between genotypes were determined by least square analysis.

\section{Results}

\subsection{Polymorphism identification and detection}

The sequences amplified with four pairs of primers (named as P1, P2, P3, and P4) were aligned among the three quail populations, and two SNPs (G373T and A313G mutations in exons 4-5 and exons 6-7, respectively, of VIPR-1 gene) were found. These polymorphisms can be detected by PCR-RFLP and sequencing. The PCR products were digested with two restriction enzymes (BsrDI for P1 and HpyCH4IV forP2). The $\mathrm{G}$ to $\mathrm{T}$ transversion for the 373 locus in exons 4-5 and the A to $\mathrm{G}$ transition at the nucleotide position 313 in exons 6-7 expressed three genotypes: GG, GT, TT and GG, AG, AA, respectively (Fig. 1).

\subsection{Allele and genotype distribution in quail populations}

Allele and genotype frequencies found at exons 6-7 of the VIPR-1 gene indicate that the G allele is

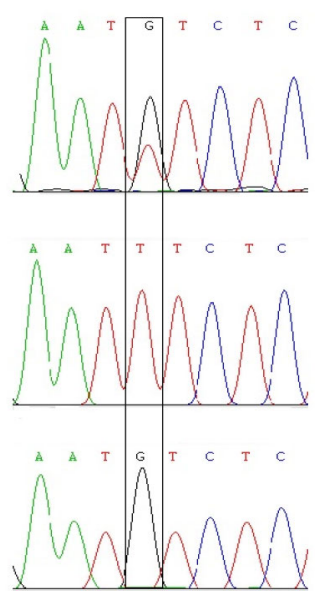

(a)

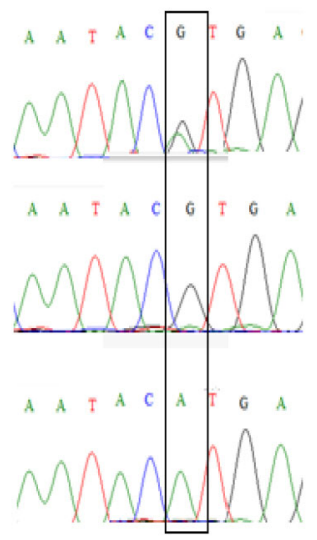

(b)
Fig. 1 Sequences amplified by primers $P 1$ and $P 2$ containing the G373T (a) and A313G (b) mutations, respectively

dominant in all the three quail populations at the A313G locus, while $\mathrm{G}$ is dominant at $\mathrm{G} 373 \mathrm{~T}$ for both the $\mathrm{H}$ line and wild quails, but not for the $\mathrm{L}$ line. The alleles of A313G and G373T in the three quail populations did not deviate from the Hardy-Weinberg equilibrium $(P<0.05$; Tables 2 and 3$)$.

\subsection{Association analysis of SNPs with egg pro- duction traits}

Table 4 shows the results of the general linear model analysis of association between the VIPR-1 gene polymorphisms and egg production traits. For the G373T locus or A313G locus in the $\mathrm{H}$ and $\mathrm{L}$ lines, the egg weight of the genotype GG was significantly higher $(P<0.05)$ than that of the genotype TT (AA). However, for the G373T locus in the $\mathrm{H}$ line, the egg number of the genotype TT at 20 weeks of age was significantly higher $(P<0.05)$ than that of the genotype GG. Likewise, for the A313G locus in the L line, the egg number of the genotype AG at 20 weeks of age was significantly higher $(P<0.05)$ than that of the genotype GG. Obviously, $\mathrm{G}$ is the dominant gene in egg weight and $\mathrm{T}$ may be the dominant gene in the egg number at 20 weeks of age.

\subsection{Linkage disequilibrium and haplotype analyses}

LD analysis of the three quail populations showed that the two SNPs were in a weak LD (Table 5), indicating that the G373T and A313T loci were not linked and this region may not be inherited as a unit. Through estimating the SNP haplotype frequencies, four haplotypes with frequencies higher 
Table 2 Distribution of G373T genotypic and allelic frequencies in all populations

\begin{tabular}{|c|c|c|c|c|c|c|}
\hline \multirow{2}{*}{ Population } & \multicolumn{3}{|c|}{ Genotype frequency } & \multicolumn{2}{|c|}{ Allele frequency1 } & \multirow{2}{*}{$\chi^{2}$} \\
\hline & TT & $\mathrm{TG}$ & GG & $\mathrm{T}$ & $\mathrm{G}$ & \\
\hline $\mathrm{H}$ line $(n=196)$ & 0.2092 & 0.5408 & 0.2500 & 0.4792 & 0.5208 & 0.2678 \\
\hline L line $(n=202)$ & 0.2475 & 0.5842 & 0.1683 & 0.5417 & 0.4583 & 1.2962 \\
\hline Wild quail $(n=45)$ & 0.1778 & 0.4889 & 0.3333 & 0.4259 & 0.5741 & $0.0318^{*}$ \\
\hline
\end{tabular}

${ }^{*} P<0.05$, the SNP locus in this population deviated from the Hardy-Weinberg equilibrium

Table 3 Distribution of A313G genotypic and allelic frequencies in all populations

\begin{tabular}{|c|c|c|c|c|c|c|}
\hline \multirow{2}{*}{ Population } & \multicolumn{3}{|c|}{ Genotype frequency } & \multicolumn{2}{|c|}{ Allele frequency } & \multirow{2}{*}{$\chi^{2}$} \\
\hline & AA & $\mathrm{AG}$ & GG & $\mathrm{A}$ & G & \\
\hline H line $(n=196)$ & 0.1480 & 0.4592 & 0.3929 & 0.3750 & 0.6250 & 0.0516 \\
\hline L line $(n=202)$ & 0.1238 & 0.4802 & 0.3960 & 0.3646 & 0.6354 & $0.0270^{*}$ \\
\hline Wild quail $(n=45)$ & 0.2000 & 0.5111 & 0.2889 & 0.4600 & 0.5400 & $0.0170^{*}$ \\
\hline
\end{tabular}

${ }^{*} P<0.05$, the SNP locus in this population deviated from the Hardy-Weinberg equilibrium

Table 4 Association of SNP of VIPR-1 gene with egg production traits in the $H$ and $L$ lines

\begin{tabular}{ccllcccc}
\hline \multirow{2}{*}{ SNP } & \multirow{2}{*}{ Line } & Genotype & \multicolumn{5}{c}{ Association of SNP with egg production traits } \\
\cline { 3 - 7 } & & $\begin{array}{c}\text { Body weight } \\
\text { at first egg }\end{array}$ & $\begin{array}{c}\text { Age at first } \\
\text { laying }\end{array}$ & Egg weight & $\begin{array}{c}\text { Body weight at } \\
\text { 20 weeks of age }\end{array}$ & $\begin{array}{c}\text { Egg number at } \\
\text { 20 weeks of age }\end{array}$ \\
\hline G373T & H & TT $(n=41)$ & $142.80 \pm 8.00$ & $45.50 \pm 1.90$ & $10.01 \pm 0.33 \mathrm{~b}$ & $153.60 \pm 12.95$ & $86.90 \pm 3.28 \mathrm{a}$ \\
& & GT $(n=106)$ & $142.62 \pm 8.29$ & $45.69 \pm 3.25$ & $10.07 \pm 0.52 \mathrm{~b}$ & $150.35 \pm 13.15$ & $85.92 \pm 6.05 \mathrm{a}$ \\
& & GG $(n=49)$ & $140.58 \pm 11.22$ & $43.83 \pm 2.41$ & $10.92 \pm 0.68 \mathrm{a}$ & $152.08 \pm 12.62$ & $81.75 \pm 7.07 \mathrm{~b}$ \\
& L & TT $(n=50)$ & $139.79 \pm 8.00$ & $46.36 \pm 1.90$ & $10.78 \pm 0.99 \mathrm{~b}$ & $156.86 \pm 12.95$ & $82.00 \pm 3.28$ \\
& & GT $(n=118)$ & $134.00 \pm 8.29$ & $46.67 \pm 3.25$ & $10.88 \pm 0.99 \mathrm{~b}$ & $155.75 \pm 13.15$ & $80.67 \pm 6.05$ \\
A313G & H & GG $(n=34)$ & $141.50 \pm 11.22$ & $49.13 \pm 2.41$ & $10.83 \pm 1.15 \mathrm{a}$ & $158.88 \pm 12.62$ & $79.75 \pm 7.07$ \\
& & AA $(n=29)$ & $145.86 \pm 5.79$ & $44.86 \pm 2.48$ & $9.79 \pm 0.27 \mathrm{~b}$ & $147.43 \pm 14.72$ & $84.43 \pm 7.25$ \\
& AG $(n=90)$ & $140.36 \pm 8.12$ & $45.77 \pm 2.93$ & $10.24 \pm 0.63 \mathrm{ab}$ & $150.82 \pm 12.75$ & $85.09 \pm 5.33$ \\
& GG $(n=77)$ & $142.84 \pm 10.43$ & $44.63 \pm 2.97$ & $10.46 \pm 0.70 \mathrm{a}$ & $153.68 \pm 12.33$ & $86.26 \pm 6.53$ \\
& L & AA $(n=25)$ & $134.33 \pm 6.35$ & $48.17 \pm 2.48$ & $10.22 \pm 1.36 \mathrm{~b}$ & $160.17 \pm 14.41$ & $75.50 \pm 4.81 \mathrm{~b}$ \\
& & AG $(n=97)$ & $138.52 \pm 10.33$ & $45.70 \pm 3.96$ & $10.51 \pm 0.94 \mathrm{~b}$ & $155.57 \pm 14.80$ & $86.26 \pm 4.40 \mathrm{a}$ \\
& GG $(n=80)$ & $140.11 \pm 13.64$ & $47.95 \pm 4.73$ & $11.34 \pm 0.69 \mathrm{a}$ & $157.53 \pm 8.90$ & $77.11 \pm 9.94 \mathrm{~b}$ \\
\hline
\end{tabular}

Data are expressed as mean \pm SD. Values followed by different alphabets differ significantly $(P<0.05)$

than $2 \%$ were identified separately in the $\mathrm{H}$ line and $\mathrm{L}$ line, including h1 (GG, 43.75\%), h2 (GT, 18.75\%), h3 (TA, 29.17\%), and h4 (GA, 8.33\%) in the H line and h1 (GG, 35.42\%), h2 (GA, 10.41\%), h3 (GT, $28.13 \%$ ), and h4 (TA, 26.04\%) in the L line. Based on the four haplotypes, seven diplotypes were obtained, with two of them having a frequency higher than $20 \%$ in the L line (Tables 5 and 6). Association analysis revealed that the diplotypes were significantly linked with egg weight in the $\mathrm{H}$ and $\mathrm{L}$ lines $(P<0.05)$. Quails with the h1h2 (GGGT or GGGA) diplotype always exhibited the smallest egg weight but the largest egg number at 20 weeks of age. A significant difference $(P<0.05)$ was observed between the diplotypes and egg weight in the L line, and quails with the h1h1 (GGGG) or h1h3 (GGGT) always exhibited the largest egg weight, but the egg number at 20 weeks of age is not significantly different $(P>0.05)$.
Table 5 Linkage disequilibrium tests of G373T and A313G loci in the VIPR-1 gene

\begin{tabular}{ccc}
\hline Line & $D^{\prime}$ & $r^{2}$ \\
\hline $\mathrm{H}$ & 0.472 & 0.145 \\
$\mathrm{~L}$ & 0.005 & 0 \\
$\mathrm{~W}$ & 0.499 & 0.159 \\
\hline
\end{tabular}

$D^{\prime}$ is above and $r^{2}$ is below the diagonal in the $\mathrm{H}, \mathrm{L}$, and $\mathrm{W}$ (wild) lines

\section{Discussion}

With the rapid development of molecular genetics, scientists can obtain large amounts of genomic information for accurate estimation of an animal's genetic and breeding values, which facilitates the research on candidate genes and their effects on phenotypic manifestations, and has established the basis for a marker-associated selection process (MAS) 
Table 6 Association analysis between diplotypes and egg production traits in the $H$ and $L$ lines

\begin{tabular}{|c|c|c|c|c|c|c|}
\hline \multirow[b]{2}{*}{ Line } & \multirow[b]{2}{*}{ Diplotype } & \multicolumn{5}{|c|}{ Association between diplotypes and egg production traits } \\
\hline & & $\begin{array}{l}\text { Body weight at } \\
\text { first egg }\end{array}$ & $\begin{array}{l}\text { Age at first } \\
\text { laying }\end{array}$ & Egg weight & $\begin{array}{l}\text { Body weight at } \\
20 \text { weeks of age }\end{array}$ & $\begin{array}{l}\text { Egg number at } \\
20 \text { weeks of age }\end{array}$ \\
\hline \multirow[t]{7}{*}{$\mathrm{H}$} & h1h1 $(n=33)$ & $139.63 \pm 13.39$ & $43.00 \pm 2.51$ & $10.78 \pm 0.66 a$ & $150.13 \pm 13.10$ & $80.38 \pm 7.71 b$ \\
\hline & h1h2 $(n=41)$ & $145.00 \pm 7.85$ & $46.00 \pm 2.87$ & $10.24 \pm 0.70 b$ & $156.60 \pm 2.25$ & $88.10 \pm 4.72 \mathrm{a}$ \\
\hline & h1h3 $(n=49)$ & $139.33 \pm 8.49$ & $46.00 \pm 3.72$ & $10.00 \pm 0.37 b$ & $146.67 \pm 0.32$ & $85.25 \pm 5.82 \mathrm{ab}$ \\
\hline & h1h4 $(n=16)$ & $142.50 \pm 5.97$ & $45.50 \pm 1.00$ & $11.20 \pm 0.71 \mathrm{a}$ & $156.00 \pm 12.36$ & $84.50 \pm 5.45 \mathrm{ab}$ \\
\hline & h2h3 $(n=24)$ & $141.00 \pm 9.51$ & $45.50 \pm 2.17$ & $10.07 \pm 0.38 \mathrm{~b}$ & $155.67 \pm 16.29$ & $85.50 \pm 2.88 \mathrm{ab}$ \\
\hline & h3h3 $(n=12)$ & $145.00 \pm 6.00$ & $46.00 \pm 1.73$ & $9.87 \pm 0.32 b$ & $149.67 \pm 7.37$ & $88.67 \pm 3.51 \mathrm{a}$ \\
\hline & h4h3 $(n=16)$ & $146.50 \pm 6.45$ & $44.00 \pm 2.83$ & $9.73 \pm 0.26 b$ & $145.75 \pm 19.70$ & $82.50 \pm 9.00 \mathrm{ab}$ \\
\hline \multirow[t]{7}{*}{$\mathrm{L}$} & h1h1 $(n=17)$ & $141.25 \pm 3.20$ & $48.25 \pm 2.06 \mathrm{ab}$ & $11.63 \pm 0.81 \mathrm{a}$ & $160.75 \pm 9.50$ & $77.00 \pm 4.24 \mathrm{~cd}$ \\
\hline & h1h2 $(n=12)$ & $144.33 \pm 8.96$ & $50.00 \pm 3.61 \mathrm{a}$ & $9.90 \pm 1.00 \mathrm{~b}$ & $152.00 \pm 8.00$ & $84.00 \pm 5.29 \mathrm{abc}$ \\
\hline & h1h3 $(n=46)$ & $140.00 \pm 15.28$ & $47.73 \pm 5.92 \mathrm{ab}$ & $11.26 \pm 0.37 \mathrm{a}$ & $158.18 \pm 8.87$ & $79.64 \pm 9.96 \mathrm{bc}$ \\
\hline & h1h4 $(n=51)$ & $141.83 \pm 10.55$ & $44.50 \pm 3.06 \mathrm{~b}$ & $10.65 \pm 1.02 \mathrm{ab}$ & $155.25 \pm 14.73$ & $87.08 \pm 4.93 a$ \\
\hline & $\mathrm{h} 2 \mathrm{~h} 4(n=21)$ & $134.40 \pm 7.09$ & $47.80 \pm 2.59 \mathrm{ab}$ & $10.18 \pm 1.52 b$ & $157.80 \pm 14.75$ & $75.00 \pm 5.20 \mathrm{~cd}$ \\
\hline & h3h3 $(n=17)$ & $139.25 \pm 18.01$ & $48.25 \pm 3.59 \mathrm{ab}$ & $11.25 \pm 1.20 \mathrm{ab}$ & $152.50 \pm 8.58$ & $70.25 \pm 12.55 \mathrm{~d}$ \\
\hline & h3h4 $(n=34)$ & $131.38 \pm 6.78$ & $45.88 \pm 4.52 \mathrm{ab}$ & $10.54 \pm 0.81 \mathrm{ab}$ & $157.38 \pm 17.86$ & $85.88 \pm 3.36 \mathrm{ab}$ \\
\hline
\end{tabular}

Data are expressed as mean \pm SD. Values followed by different alphabets differ significantly $(P<0.05)$

(Kulibaba and Podstreshnyi, 2012). However, the research on the quail at the genetic level is just in the initial stages and little information is available currently (Roussot et al., 2003; Kayang et al., 2004; Beaumont et al., 2005; Mo et al., 2013; Recoquillay et al., 2015).

Laying quail is an important economic animal. In the present study, the $\mathrm{H}$ and $\mathrm{L}$ lines were selected for different breeding goals, with a higher egg number for the former and a higher egg weight for the latter. Additionally, we chose the VIPR-1 as the candidate gene and found two SNPs (A313G and G373T). Gene frequency calculation found that different groups in the same mutation locus have a different dominant gene, with the $G$ allele dominant at the A313G locus in all of the three quail populations and at the G373T locus in the $\mathrm{H}$ line and wild quails. Meanwhile, the $\mathrm{G}$ allele is dominant in the wild quail just like in the $\mathrm{H}$ line. Thus, we can speculate that the wild quail has a larger egg production potential, which has not been reaped due to lack of domestication and a suitable breeding environment. However, the $\mathrm{T}$ allele has a higher ratio than the $\mathrm{G}$ allele at the G373T locus in the L line, which is different from the A313G locus and might have resulted from the interaction between genetic loci, especially artificial selection.

Furthermore, the polymorphisms of the VIPR-1 gene were found to be associated with egg weight of the quails in both the $\mathrm{H}$ and $\mathrm{L}$ lines, and a significant association was also found between genotypes (diplotypes) and egg numbers in the $\mathrm{H}$ line at 20 weeks of age, suggesting that the $\mathrm{H}$ line has a greater potential in egg production. Therefore, we inferred that the allele A (T) is dominant as an egg production trait, and the allele $\mathrm{G}$ is dominant for egg weight in the two mutations of the VIPR-1 gene. We analyzed the G allele and found it is higher in the $\mathrm{H}$ line than in other populations, which may have resulted from reproduction of special groups.

Hence, our findings in the present study demonstrate that G373T and A313G of the VIPR-1 gene can be used for selecting the high yield or egg weight strain in quails. Additionally, the VIPR-1 gene could be used not only as an important candidate gene for egg production in quails but also as a genetic marker in molecular marker-assisted selection for quail reproduction traits.

In summary, two SNPs (A313G and G373T) have been identified in the exons 4-5 and exons 6-7 of the quail VIPR-1 gene, which are likely to be the causative mutations of two SNPs in their reproduction traits. Therefore, VIPR- 1 is probably an important gene in egg production traits of quails and can also be used as a marker-assisted selection for traditional breeding.

\section{Acknowledgements}

We sincerely thank Jin-song PI (Hubei Academy of Agriculture Sciences, China) for providing valuable help for this study. 


\section{Compliance with ethics guidelines}

Yue-jin PU, Yan WU, Xiao-juan XU, Jin-ping DU, and Yan-zhang GONG declare that they have no conflict of interest.

All institutional and national guidelines for the care and use of laboratory animals were followed.

\section{References}

Beaumont, C., Roussot, O., Feve, K., et al., 2005. A genome scan with AFLP TM markers to detect fearfulness-related QTLs in Japanese quail. Anim. Genet., 36(5):401-407. http://dx.doi.org/10.1111/j.1365-2052.2005.01336.x

Chaiseha, Y., Youngren, O.M., el Halawani, M.E., 2004. Expression of vasoactive intestinal peptide receptor messenger RNA in the hypothalamus and pituitary throughout the turkey reproductive cycle. Biol. Reprod., 70(3): 593-599.

http://dx.doi.org/10.1095/biolreprod.103.022715

Clarke, K.R., Gorley, R.N., 2001. Primer v5: User Manual/ Tutorial. Plymouth: PRIMER-E, Plymouth, UK, p.99.

el Halawani, M.E., Silsby, J.L., Mauro, L.J., 1990. Vasoactive intestinal peptide is a hypothalamic prolactin-releasing neuropeptide in the turkey (Meleagris gallopavo). Gen. Comp. Endocr., 78(1):66-73. http://dx.doi.org/10.1016/0016-6480(90)90048-Q

Kansaku, N., Shimada, K., Ohkubo, T., et al., 2001. Molecular cloning of chicken vasoactive intestinal polypeptide receptor complementary DNA, tissue distribution and chromosomal localization. Biol. Reprod., 64(5):15751581 . http://dx.doi.org/10.1095/biolreprod64.5.1575

Kayang, B.B., Vignal, A., Inoue-Murayama, M., et al., 2004. A first-generation microsatellite linkage map of the Japanese quail. Anim. Genet., 35(3):195-200. http://dx.doi.org/10.1111/j.1365-2052.2004.01135.x

King'ori, A.M., 2011. Review of the factors that influence egg fertility and hatchability in poultry. Int. J. Poult. Sci., 10(6):483-492. http://dx.doi.org/10.3923/ijps.2011.483.492

Kulibaba, R.A., Podstreshnyi, A.P., 2012. Prolactin and growth hormone gene polymorphisms in chicken lines of Ukrainian selection. Cytol. Genet., 46(6):390-395. http://dx.doi.org/10.3103/S0095452712060060

Li, J., 2014. Estrogen stimulates expression of chicken hepatic vitellogenin II and very low-density apolipoprotein II through ER- $\alpha$. Theriogenology, 82(3):517-524. http://dx.doi.org/10.1016/j.theriogenology.2014.05.003

Miazi, O.F., MIAH, G., Miazi, M.M., et al., 2012. Fertility and hatchability of Fayoumi and Sonali chicks. JAS, 2:83-86.

Mo, F., Zheng, J., Wang, P., et al., 2013. Quail FMO3 gene cloning, tissue expression profiling, polymorphism detection and association analysis with fishy Ttaint in Eggs. PLOS ONE, 8(11):1434-1434.

http://dx.doi.org/10.1371/journal.pone.0081416

Recoquillay, J., Pitel, F., Arnould, C., et al., 2015. A medium density genetic map and QTL for behavioral and production traits in Japanese quail. BMC Genomics, 16(1):10. http://dx.doi.org/10.1186/s12864-014-1210-9

Roussot, O., Feve, K., Plisson-Petit, F., et al., 2003. AFLP linkage map of the Japanese quail Coturnix japonica. Genet. Sel. Evol., 35(6):559-572. http://dx.doi.org/10.1186/1297-9686-35-6-559

Rozenboim, I., el Halawani, M.E., 1993. Chracterization of vasoactive intestinal peptide pituitary membrane receptors in turkey hens during different stages of reproduction. Biol. Reprod., 48(5):1129-1134. http://dx.doi.org/10.1095/biolreprod48.5.1129

You, S., Hsu, C.C., Kim, H., et al., 2001. Molecular cloning and expression analysis of the turkey vasoactive intestinal peptide receptor. Gen. Comp. Endocr., 124(1):53-65. http://dx.doi.org/10.1006/gcen.2001.7685

Zhou, M., Ying, L., Shen, X., et al., 2012. cDNA cloning, sequence analysis and tissue specific expression of vasoactive intestinal peptide type 1 receptor $(V I P R-1)$ in quails. China Agric. Sci., 45(3):529-539 (in Chinese). http://dx.doi.org/10.3864/j.issn.0578-1752.2012.03.015

\section{中文概要}

题 目: VIPR-1 基因多态性及其单倍型与蛋用鹤敦产蛋 性能的相关性研究

目 的: 蛋用鹤敦 VIPR-1 基因单核苷酸多态性 (SNP) 研究。

创新点: 首次开展蛋用鹤鹑 VIPR-1 基因多态性研究, 发 现了两个与蛋重相关的多态性位点。

方 法: 以 VIPR-1 基因设计引物, 进行聚合酶链式反应限制片段长度多态性分析, 获得基因突变位点。 并通过关联性分析, 研究基因多态性与繁殖性状 之间的相关性。

结 论: 在个体数为 443 个 (202 只 $\mathrm{L}$ 个体、196 只 $\mathrm{H}$ 个 体和 45 只野生鹤敦个体) 的群体中发现两个突 变位点 (G373T 和 $A 313 G$ ), 且两位点间存在微 弱的连锁不平衡。相关性分析表明, SNP 多态性 与鹤敦蛋重之间存在明显的相关性。组成的 7 个 主要二倍型中, 含有 $\mathrm{h} 1 \mathrm{~h} 2$ (GGGT) 的个体总是 表现为较小的蛋重及较大的产蛋数。

关键词: 血管活性肠肽; 多态性; 单倍型; VIPR-1 基因; 产蛋性能相关性 